\title{
Firm Performance and Its Drivers: How Important Are the Industry and Firm-Level Factors?
}

\author{
Olubanjo Michael Adetunji ${ }^{1} \&$ Akintola Amos Owolabi ${ }^{1}$ \\ ${ }^{1}$ Department of Accounting, Finance \& Economics, Lagos Business School, Pan-Atlantic University, Nigeria \\ Correspondence: Olubanjo M. Adetunji, Department of Accounting, Finance \& Economics, Lagos Business \\ School, Pan-Atlantic University, Km 22 Lekki-Epe Expressway, Ajah, Lagos, Nigeria. Tel: 234-816-4514-210. \\ E-mail: oadetunji@lbs.edu.ng
}

Received: August 30, 2016

Accepted: September 20, 2016

Online Published: October 25, 2016

doi:10.5539/ijef.v8n11p60

URL: http://dx.doi.org/10.5539/ijef.v8n11p60

\begin{abstract}
This paper provides empirical evidence for the relative importance of industry and firm-level factors as determinants of firm performance. It also shows the relevance of the individual factors at both industry and firm levels. The paper therefore attempts to provide evidence for effects of industry and business-specific factors on firm performance using data from a developing economy. The study uses the financial and other organization-specific data of firms listed on the Nigerian Stock Exchange. The findings show that organization-specific factors are relatively more important than the industry factors, accounting for 66.58 percent of the variation in return on asset with little or no evidence for the effects of industry-level factors on return on asset. Financial leverage, firm size and firm growth rate are shown to be the most relevant firm-level factors. Firm-level factors also account for slightly more variance in Tobin's $Q$ than the industry factors. The results also show that the industry sector of the firm is the most relevant industry-level determinant of firm market performance. There is however little or no evidence for the effects of both industry- and firm-level factors on return on equity.
\end{abstract}

Keywords: firm performance, market performance, industry organization, financial leverage, firm size

\section{Introduction}

Firm performance is a very broad management topic. A number of factors and their effects on firm performance have been studied by management researchers. The key performance measures of a firm include such financial measures as earning per share (EPS), return on asset (ROA), return on equity (ROE) and return on sale (ROS) among other. However firm performance has also been measured using non-financial measures that affect their image such as their corporate social responsibility (CSR) efforts such as the use of 'green' materials, charitable contributions, ethics training/enforcement and workforce diversity programmes. Although these efforts impact negatively on the financial performance of the firm in the short term, they have been shown to positively affect the firm's financial performance in the long run (Ahamed, Almsafir, \& Al-Smadi, 2014; Brammer \& Millington, 2008; Eisenbeiss, Knippenberg, \& Fahrbach, 2015; Nielsen \& Nielsen, 2013; Richard, 2000). This explains why most of the studies on factors affecting firm performance have used the financial performance measures. The factors identified in the literature as drivers of firm performance can be broadly grouped into industry-related factors and organization-specific factors. While industry organization theorists view industry factors as the primary determinants of firm performance (Bain, 1954; Schmalensee, 1985) their business-strategy counterparts suggest that a firm's unique resources and capabilities are the primary drivers of firm's profitability (Barney, 1991; Barney, 2011; Wernerfelt, 1984; Wernerfelt, 2013). Therefore, two alternative views coexist about the relative importance of industry and organizational factors of firm profitability (Chaddad \& Mondelli, 2013).

This study attempts to provide empirical evidence for the relative importance of industry- and business-specific factors using data from a developingeconomy. Developing economies like Nigeria have recorded relatively high economic growth when compared to growth rates in developed economies. Nigeria is named among the next 11 emerging economies by Goldman Sachs Group Inc., it is therefore necessary to see whether the industry- and firm-level factors in emerging economies affect firm performance in a way similar to the effects of these factors on firm performance in developed economies. Both industry and firm-specific factors have been shown to affect firm performance mostly in the developed economies (Bowman \& Helfat, 2001; Chaddad \& Mondelli, 2013; 
Goddard, Tavakoli, \& Wilson, 2005; Graham, Lemmon, \& Wolf, 2002; Gschwandtner, 2012; McGahan \& Porter, 1997; Roquebert, Phillips, \& Westfall, 1996; Rumelt, 1991; Schmalensee, 1985; Short, Ketchen Jr., Bennett, \& du Toit, 2006). It has been shown that industry-level factors such as the type of the industry, the growth rate of the industry and the nature of barrier to entering the industry affect the performance of firms in the industry. In the same manner, extant studies have shown that firm-level characteristics including firm size, firm age, relative market share and firm growth rate also affect firm profitability. A number of these studies however show that business-specific factors are relatively more important than the industry-level factors. This paper therefore attempts to provide evidence for the relative importance of industry- and firm-level factors on firm performance using data from the firms listed on the Nigerian Stock Exchange. The findings are compared with findings in extant literature including those of McGahanand Porter (McGahan \& Porter, 1997) that business-specific factors contribute more than 30 percent to firm profitability while industry factors are responsible for about 20 percent of firm performance.

While it is easier to identify the key industry factors that drive firm profitability, the business-specific factors responsible for firm performance are however many and cut across different topics in management. These organization-specific factors have been studied by management researchers and their incremental contributions to firm performance explored. Although these business-specific factors are mainly from strategic management and organization theory \&behaviour, the effects of other factors from operations, management information system, strategic human resource management, business ethics and finance have also been explored. These include the effects of characteristics of founders, chief executive officers (CEOs) and board on firm performance (Dencker \& Gruber, 2015; Kaczmarek, Kimino, \& Pye, 2014; Peni, 2014; Yang \& Zhao, 2014), diversification (Hashai, 2015) and effects of outsourcing on firm performance (Arvanitis \& Loukis, 2013). Other factors studied include change in governance environment (Yang, 2013), corporate social responsibility (Jayachandran, Kalaignanam, \& Eilert, 2013), unionization (Anwar \& Sun, 2015), collective organizational engagement (Barrick, Thurgood, Smith, \& Courtright, 2015), internalization (Giovannetti, Ricchiuti, \& Velucchi, 2013) and leadership succession (Chung \& Luo, 2013). Resource orchestration in SHRM (Chadwick, Super, \& Kwon, 2015) and entrepreneurial factors (Arend, 2014; Shehu \& Mahmood, 2014) have also been shown to affect firm performance. In finance such factors as working capital management, taxes \& theft, ownership structure and portfolio concentration and the their relationships with firm profitability have also been explored (Aktas, Croci, \& Petmezas, 2015; Ekholm \& Maury, 2014; Huang \& Boateng, 2013; Mironov, 2013). Finally the effects of technology-related factors, operational efficiency and business ethics on firm profitability have equally been the subject of studies on firm performance literature (Baik, Chae, Choi, \& Farber, 2013; Eisenbeiss, Knippenberg, \& Fahrbach, 2015; Chae, Koh, \& Prybutok, 2014; Piget \& Kossai, 2013 ; Shan \& Jolly, 2013).

This section provides research background to the study on the relative effects of industry and business-specific factors on firm performance. The next section reviews the literature firm performance including the theories that have been used to explore firm performance. The section also reviews the literature on the relative importance of industry and firm-level drivers of firm profitability. Section three discusses the suitability of the methodology used in the paper and also includes the discussions on the sample and the data used in the study including the development of models for the analysis of the data. Findings from the analysis are discussed in the fourth section while section five concludes the paper.

\section{Firm Performance and Its Drivers}

The primary objective of the firm is the maximization of profit. Profit is driven by revenues and costs. Thus a firm can maximize profit by maximizing revenues and/or minimizing costs. The study of firm profitability or firm performance therefore has its origin on the various studies that have examined the drivers of revenues and costs. The various studies have produced theories of the firm with various empirical studies conducted to provide support for these theories. Other studies have also attempted to extend these theories. Key among these theories of the firm are boundary of the firm, transaction cost economics (TCE) and agency theory. The field of industrial organization (IO) builds on the theories of the firm and explores how the structure of the firms determines the individual behaviour of the firm which then determines their profitabilities. In other word, the IO researchers argue that structure of the industry in which a firm chooses to operate determines its profitability. On the other hand the new empirical industrial economists (NEIO) (Church \& Ware, 2000) now also known as strategic management scholars believe the business-specific strategies or conducts play the defining roles in firm performance.

\subsection{Industry versus Strategic Management: Empirical Evidences}

New empirical industrial organization (NEIO) studies situate the determinants of firm performance with the 
conduct of the firm. This is also the thinking of strategic management or resource-based view (Barney, 1991; Wernerfelt, 1984) of the firm. A number of studies have been conducted to provide empirical evidences for the relative importance of the industry and business-specific factors in the determination of firm performance. Schmalensee (Schmalensee, 1985) in its study using the 1975 data from the Line of Business Program of the U.S. Federal Trade Commission (FTC) shows that no firm effects exist and that industry effects exist and account for at least 75 percent of the variance of industry rates of return on assets. On the other hand, Rumelt in his study (Rumelt, 1991) distinguishes between stable and fluctuating effects in the FTC Line of Business data and shows that there are negligible corporate effects, small stable industry effects and very large stable business unit effects. Roquebert et al (Roquebert, Phillips, \& Westfall, 1996), in their study confirm Rumelt'sfindings that business-specific factors are more important than the industry factors in the determination of firm profitability. Their findings also suggest the existence of corporate effects hitherto undetected.

Follow-on study by McGahan and Porter (McGahan \& Porter, 1997) that examines the profitability of U.S. public corporations indicates that year, industry, corporate-patent and business-specific effects account for 2 percent, 19 percent, 4 percent and 32 percent respectively of the aggregate variance in profitability. Their findings therefore show that business-specific factors, at 32 percent, explain greater variances in the profitability of firms considered in the study. Findings from other recent studies have confirmed this position. These include the study that shows the noticed corporate effects are due to corporate strategy elements of the firm (Bowman \& Helfat, 2001). The authors differentiate between business and corporate strategy. While business strategy deals with the ways in which a single-business firm operates within a particular industry, corporate strategy, they say, deals with the ways in which a corporation manages a set of business together. This study including most of the earlier ones used the variance decomposition approach. Another study however employs another approach that uses a pooled cross-sectional and time-series or a panel data analysis of the industry and business-specific variables to determine their relative importance to firm profitability (Goddard, Tavakoli, \& Wilson, 2005). The authors use the data of manufacturing and service sector firms in selected European countries. Chaddad and Mondelli (Chaddad \& Mondelli, 2013), in their study of large panel of food economy firms, use hierarchical linear modelling (HLM) approach to also show that business unit and corporate effects are more relevant than industry effects in explaining firm performance differences among the selected firms. To further underscore the importance of firm performance in the field of management, a study attempts to explore the drivers of firm performance by developing and testing its measurement model using confirmatory factor analysis (CFA) (Santos $\&$ Brito, 2012). The authors show that the six first-order dimensions of firm performance are profitability, growth, customer satisfaction, employee satisfaction, social performance and environmental performance. The six dimensions found in the study can be broadly grouped together into industry and firm-specific factors. The study thus offers support to other extant studies on firm performance that the major drivers of firm profitability are industry and organizational factors.

\subsection{Other Determinants of Firm Performance}

Although the major drivers of firm profitability have been identified in the literature, several other studies have been conduced to examine the effects of constructs from various areas of management on firm performance. These factors are majorly organization-specific and include the non-traditional firm-specific variables. These factors include diversification, capital structure, ownership structure, unionisation, information \& communication technology, entrepreneurial and other qualities/characteristics of the owners and directors of the firms.For example diversification has been argued to help firms manage fluctuations in their revenues and thus hypothesized to lead to improved firm performance. The within-industry diversifications of firms and their effects on firm performance have been studied with mixed results (Graham, Lemmon, \& Wolf, 2002; Hashai, 2015). The mode and the scope of diversification are examples of factors that have shown to affect the relationship between diversification and firm performance. The degree of positive or negative effect of diversification on profitability will depend on whether it is done through merger/acquisition or through organic growth. The relationship is also affected by the scope of the diversification as there may be a negative relationship once the optimal level is surpassed. Capital and ownership structure of the firm have also been shown to drive firm profitability (Aktas, Croci, \& Petmezas, 2015; Fosu, 2013; Huang \& Boateng, 2013; Kahle \& Shastri, 2005; Yang \& Zhang, 2013). The findings of these studies have also been mixed as the relationship has been shown to be affected by some other factors.

Unionisation has been shown to play key mediating role in how other constructs affect firm performance in management (Anwar \& Sun, 2015; Church \& Ware, 2000). Managerial decisions that have direct effect on unionized firm performance have been shown to be delayed, twisted or even abandoned. Profits that would have positively affected firms' bottom lines have also been shown to be directed to employee benefits in unionized 
firms in forms of increased employee wages/salaries and other benefits. On the other hand, studies have shown that ICT infrastructures have not only improved operational efficiency of firms but have also given the firms strategic competitive advantage (Chae, Koh, \& Prybutok, 2014; Piget \& Kossai, 2013; Shan \& Jolly, 2013). However the positive performance effects of ICT are no longer visible especially in the last decade as the ICT capabilities become increasingly commoditised and therefore no longer give a firm a competitive edge. Entrepreneurial and other characteristics of the firm owners and managers, including the board of directors, have also been shown to affect firm profitability. The studies include how entrepreneurial opportunities and founder experience shape performance outcomes of new firms (Dencker \& Gruber, 2015) and whether or not differences in dynamic capabilities of entrepreneurial opportunities have positive effects on small firms'profitabilities (Arend, 2014). The characteristics of CEO and chairpersons (Peni, 2014), interlocking directorships (Kaczmarek, Kimino, \& Pye, 2014), CEO duality (Yang \& Zhao, 2014) and leadership successions (Chung \& Luo, 2013) are constructs in strategic management that have been studied and their effects on firm performance investigated. Other strategic factors studied in the literature in relation to firm performance include collective organizational engagement (Barrick, Thurgood, Smith, \& Courtright, 2015), change in governance environment (Yang, 2013), taxes and theft (Mironov, 2013), resource orchestration (Chadwick, Super, \& Kwon, 2015) and changes in operational efficiency (Baik, Chae, Choi, \& Farber, 2013). Some other constructs investigated include portfolio concentration (Ekholm \& Maury, 2014), outsourcing (Arvanitis \& Loukis, 2013), location/internationalization (Giovannetti, Ricchiuti, \& Velucchi, 2013), product \& environmental social performance (Jayachandran, Kalaignanam, \& Eilert, 2013) and firm's ethical leadership (Eisenbeiss, Knippenberg, \& Fahrbach, 2015).

\subsection{The Effects of Industry-and Firm-Level Factors on Firm Performance}

The key industry-level factors explored in this paper include industry concentration, industry capital intensity, industry research \& development (R\&D) intensity, industry growth rate and the specific sector to which the firm belongs. On the other hand, the firm-level variables examined in this paper include relative market share, firm size, diversification, financial leverage, firm age, firm capital intensity, firm R\&D intensity and firm growth rate. It is expected that the higher the industry concentration, the less the level of competition in the industry therefore the firms controlling the industry are more like to have superior performance. In the same manner the higher the intensities of capital and R\&D in the industry, the higher the barrier to entry for new players and thus the higher the expected performance of the firms in the industry. In terms of industry growth rate, it is hypothesized that superior growth rate in the industry signals superior performance of the firms in the industry. Last it is argued that the industry in which a firm belongs will affect its performance.

At the firm level, it is suggested that a firm with a relatively high relative market share will be more profitable when compared with firms with low relative market shares. This study also explores the effect of firm size on firm performance. It is argued that larger firms are likely to be more profitable than smaller firms because they enjoy economies of scale of their sizes. Diversification is expected to help a firm manage risks inherent in the demand for its products; it is hypothesized that the more diversified a firm is, the higher is its expected performance. The demands for a firm's products are less likely to be negatively affected at the same especially if the products are not related. Financial leverage relates to the proportion of debt to equity capital for the firm's financing. A highly levered firm in financed more with debt capital than equity capital and is expected to be more profitable because debt capital is cheaper than equity capital. Firm age is also hypothesized to have positive effect on firm performance as older firms are assumed to have superior capabilities as a result of their relatively long years of operation. Firms with high capital and R\&D intensities spend more on capital assets and R\&D when compared to other firms with the same level of sales. They are therefore expected to be more profitable as they are likely to enjoy more returns on their superior capital and R\&D investments. Lastly, it is hypothesized that firms that record superior rates of growth in their revenues are likely to be more profitable than firm with relatively low growth rates. This paper also sets out to determine whether the industry and/or the business specific have any effect on firm performance and the relative importance of these factors.

\section{Method}

This section analyses the relationships between the industry factors and firm performance on one hand and the relationship between the firm-level factors and firm performance on the other hand. The results are then compared to determine the relative importance of industry- and firm-level factors on firm performance. The industry- and firm-level data of the firms listed on the Nigerian Stock Exchange (NSE) are used in the analysis. The effects of these firm/industry variables on firm performance are investigated using panel data modelling. The required financial data of companies listed on all the sectors of the NSE excluding the financial services sector were sourced from the published financial reports of these firms and from Bloomberg. 


\subsection{Sample and Data}

The financial data of the firms listed on the non-financial sectors of the NSE are used in this paper. These sectors include agriculture, construction/real estate, consumer goods, healthcare, industrial goods and information \& communication technology. Others are natural resources, oil \& gas, services, utilities and conglomerates. The financial data were extracted from published financial reports of these quoted firms and from Bloomberg. Bloomberg also provides the market data including the share prices of the companies used in this paper. The firm-specific variables are either direct or computed figures from the published income and/or balance sheet statements of the companies. The share prices used come from the stock value reports of Bloomberg for the companies used in this study. The data used cover a period of five years: from year 2010 to year 2014 for the 130 firms considered in this study for a total of 650 firm-year data. However, 114 firms have their complete five-year data used in this study for a total of 570 firm-year data. The sourced data constitute the data needed for the industry variables, firm-specific variables and measures of firm performance.

\subsubsection{Industry Variables}

The industry explanatory variables used in this study are industry concentration, industry capital intensity, industry R\&D intensity, industry growth rate and industry sectors of the firms. These variables are as defined in the data definition section and their values are estimated from the relevant data extracted from the companies' financial statements.

\subsubsection{Firm-Specific Variables}

Firm-specific variables estimated from the sourced data include relative market share, firm size, diversification, financial leverage and firm age. Others include firm capital intensity, firm $R \& D$ intensity and firm growth rate

\subsubsection{Firm Performance Variables}

Three measures are used to measure firm performance. These are return on asset (ROA), return on equity (ROE) and Tobin's Q ratio. The degree of financial leverage of a firm separates ROA from ROE. Without corporate debt, ROA and ROE figures will be the same. It is therefore necessary to compare ROA and ROE values in determining firm performance especially when the firm is leveraged. Tobin's $Q$ ratio incorporates market performance into the measurement of firm performance. It compares the market value of a firm with the book value of the same firm. The results from effects of the industry and firm-level variables on the three measures of performance are analysed and then compared to determine the relative importance of the factors.

\subsubsection{Data Definition}

The independent and the dependent variables to be used in this paper are summarised in Table 1.

Table 1. Descriptions of variables

\begin{tabular}{|c|c|c|}
\hline Variable & Type / Level & Description \\
\hline $\begin{array}{l}\text { Industry } \\
\text { Concentration }\end{array}$ & Industry & $\begin{array}{l}\text { The measure used is four-firm concentration ratio which is the total percentage market shares of } \\
\text { the four largest firms in the industry in a year }\end{array}$ \\
\hline $\begin{array}{l}\text { Industry } \\
\text { Intensity }\end{array}$ & Industry & $\begin{array}{l}\text { Average of the net value of property, plant and equipment to net sales across all firms in the } \\
\text { industry for each year }\end{array}$ \\
\hline $\begin{array}{l}\text { Industry } \\
\text { Intensity }\end{array}$ & Industry & $\begin{array}{l}\text { Average of the ratio of the research and development expenditure to net sales across all firms in } \\
\text { the industry for each year }\end{array}$ \\
\hline Industry Growth Rate & Industry & Annual average rate of growth of net sales for firms in the industry \\
\hline Industry Sector & Industry & The sectors in which the firms are listed \\
\hline Relative Market Share & Firm & $\begin{array}{l}\text { Ratio of the firm's market share (the firm's net sales to the total net sales of all firms in the } \\
\text { industry) to the market share the firm does not control (the firm's market share subtracted from } \\
\text { one) in a year }\end{array}$ \\
\hline Firm Size & Firm & The natural logarithm of the value of book assets of the firm for each year \\
\hline Diversification & Firm & $\begin{array}{l}\text { Number of sub-sectors in the industry for which the firm's products and services are reported for } \\
\text { each year }\end{array}$ \\
\hline Financial Leverage & Firm & The ratio of the firm's book value of debt to total assets in a year \\
\hline Firm Age & Firm & The difference between the current year and the founding year or incorporation year of the firm \\
\hline Firm Capital Intensity & Firm & The net value of property, plant and equipment to net sales of the firm for each year \\
\hline Firm R\&D Intensity & Firm & The ratio of R\&D expenditure to net sales of the firm for each year \\
\hline Firm Growth Rate & Firm & Annual rate of growth of net sales of the firm \\
\hline Return on Asset & Performance & The ratio of the firm annual net income to total assets \\
\hline Return of Equity & Performance & The ratio of the firm annual net income to average shareholders' equity \\
\hline Tobin's Q Ratio & Performance & The ratio of the total market value of firm to total book value of assets for each year \\
\hline
\end{tabular}




\subsection{The Method of Analysis}

Regression models for panel data analysis are employed to analyse the data over the five- year period. The data is first analysed using pooled ordinary least square (OLS) regression models. The panel data is then analysed for individual and/or group effects using fixed effect and random effect modelling. Regression models which include the industry and the firm-specific independent variables will be specified for the three dependent variables to be used for the analysis. With fixed effects models to be used in this study, it is assumed that some company-specific factors may bias the effects of the industry- and firm-level factors on firm performance variables and therefore needed to be controlled. The effects of these factors, that do not change with time, are controlled for using fixed effect modelling in order to analyse net effects of the identified independent variables on firm performance. On the other hand, random effects models examine the effects of the differences in company-specific factors on firm performance. The regression models will thus take the form of the pooled least squares (POLS) models, fixed effects models and random effects models.

Pooled OLS assume that there are no unobserved firm-specific effects. Fixed and random effects models are then developed to analysed the fixed effects and the random effects of the above-identified relationships respectively. To test whether fixed effects exist in the panel data, F-test is conducted on the model for each of the relationship. The test shows whether or not the fixed effect model produces better goodness-of-fit. On the other hand for random effect models, Lagrange multiplier (LM) test is carried out to show whether random effects are significant in the models examined. Finally Hausman test is carried on the models for each relationship studied in this paper to compare the relative effects of fixed and random effects on the models. The test suggests the model with the better goodness-of-fit for analysing the relationship under study.

\subsection{The Model Specifications}

\subsubsection{Models for the Effects of Industry Factors on Firm Performance}

The models for the effects of the industry variables used in this paper on each of the firm performance measures are first developed. The industry variables include industry concentration, industry capital intensity, industry R\&D intensity and industry growth. The binary variables indicating the sector in which the firm is listed is also included in the model. The firm performance measures are return on asset, return on equity and Tobin's $Q$. The three model types: pooled OLS, fixed effects and random effects, are specified for each relationship. The pooled OLS models for the effects of the industry factors on return of asset, return on equity and Tobin's Q are specified in 1,2 and 3 respectively.

$$
\begin{aligned}
& \text { roa }_{i}=\beta_{0,1}+\beta_{1,1} \text { ind }_{\text {conc }_{i, 1}}+\beta_{2,1} \text { ind }_{\text {capint }_{i, 1}}+\beta_{3,1} \text { ind }_{\text {rdint }_{i, 1}}+\beta_{4,1} \text { ind }_{\text {growth }_{i, 1}}+ \\
& \beta_{5,1} \text { agric }_{i, 1}+\beta_{6,1} \text { conglom }_{i, 1}+\beta_{7,1} \text { const }_{r e_{i, 1}}+\beta_{8,1} \text { cons }_{\text {goods }_{i, 1}}+\beta_{9,1} \text { healthcare }_{i, 1}+\beta_{10,1} i \text { ct }_{i, 1}+ \\
& \beta_{11,1} \text { ind_goods } s_{i, 1}+\beta_{12,1} \text { nat_resrc } i_{i, 1}+\beta_{13,1} \text { oil_gas }_{i, 1}+\varepsilon_{i, 1}
\end{aligned}
$$

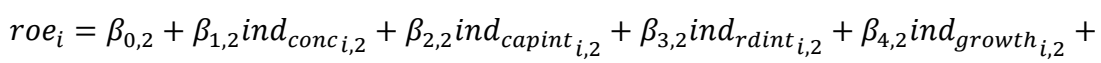

$$
\begin{aligned}
& \beta_{5,2} \text { agric }_{i, 2}+\beta_{6,2} \text { conglom }_{i, 2}+\beta_{7,2} \text { const }_{r i, 2}+\beta_{8,2} \text { cons }_{\text {goods }_{i, 2}}+\beta_{9,2} \text { healthcare }_{i, 2}+\beta_{10,2} \text { ict }_{i, 2}+ \\
& \beta_{11,2} \text { ind_goods }_{i, 2}+\beta_{12,2} \text { nat_resrc }_{i, 2}+\beta_{13,2} \text { oil_gas }_{i, 2}+\varepsilon_{i, 2} \\
& \text { tobinq }_{i}=\beta_{0,3}+\beta_{1,3} \text { ind }_{\text {conc }_{i, 3}}+\beta_{2,3} \text { ind }_{\text {capint }_{i, 3}}+\beta_{3,3} \text { ind }_{\text {rdint }_{i, 3}}+\beta_{4,3} \text { ind }_{\text {growth }_{i, 3}}+\beta_{5,3} \text { agric }_{i, 3}+ \\
& \beta_{6,3} \text { conglom }_{i, 3}+\beta_{7,3} \text { const }_{r e_{i, 3}}+\beta_{8,3} \text { cons }_{\text {goods }_{i, 3}}+\beta_{9,3} \text { healthcare }_{i, 3}+\beta_{10,3} \text { ict }_{i, 3}+ \\
& \beta_{11,3} \text { ind_goods }_{i, 3}+\beta_{12,3} \text { nat_resrc } \boldsymbol{i}_{i, 3}+\beta_{13,3} \text { oil_gas }_{i, 3}+\varepsilon_{i, 3}
\end{aligned}
$$

where roa $_{i}$, roe $_{i}$ and tobinq $q_{i}$ are firm performance measures; return on asset, return on equity and Tobin's $\mathrm{Q}$ for each year i respectively; $\beta_{0,1}, \beta_{0,2}$ and $\beta_{0,3}$ are the intercepts of the three models; ind_conc $\mathrm{i}_{\mathrm{i}, 1}$, ind_conc $\mathrm{i}_{\mathrm{i}, 2}$ and ind_conc $\mathrm{i}_{1,3}$ are the industry concentration variables for the three performance measures; ind_capint $_{\mathrm{i}, 1}$, ind_capint $_{\mathrm{i}, 2}$ and ind_capint $\mathrm{i}_{\mathrm{i}, 3}$ are the industry capital intensity variables; ind_rdint $\mathrm{i}_{\mathrm{i}, 1}$, ind_rdint $\mathrm{i}_{\mathrm{i}, 2}$ and ind_rdint $\mathrm{i}_{\mathrm{i}, 3}$ are the industry $\mathrm{R} \& \mathrm{D}$ intensity variables; ind_growth $\mathrm{i}_{\mathrm{i}, 1}$, ind_growth $\mathrm{i}_{\mathrm{i}, 2}$ and ind_growth $\mathrm{i}_{\mathrm{i}, 3}$ are the industry growth rates variables while agric $\mathrm{i}_{\mathrm{i}, \mathrm{j}}$, conglom $_{\mathrm{i}, \mathrm{j}}$, const_re $\mathrm{i}_{\mathrm{i}, \mathrm{j}}$, cons_goods $\mathrm{s}_{\mathrm{i}, \mathrm{j}}$, healthcare $\mathrm{i}_{\mathrm{i}, \mathrm{j}}$, ict $\mathrm{ic}_{\mathrm{i}, \mathrm{j}}$, ind_goods $\mathrm{s}_{\mathrm{i}, \mathrm{j}}$, nat_resrc $\mathrm{i}_{\mathrm{i}, \mathrm{j}}$, oil_gas $\mathrm{i}_{\mathrm{j}, \mathrm{j}}(\mathrm{j}=1,2,3)$ are agriculture, conglomerates, construction/real estates, consumer goods, healthcare, information \& communication technology, industrial goods, natural resources and oil \& gas sectors respectively; $\beta_{1,1}, \beta_{1,2}$ and $\beta_{1,3}$ are the coefficients for the industry concentration variables for the roa, roe and tobinq models respectively; $\beta_{2,1}, \beta_{2,2}$ and $\beta_{2,3}$ are the coefficients for the industry capital intensity variables; $\beta_{3,1}, \beta_{3,2}$ and $\beta_{3,3}$ are the coefficients for the industry R\&D intensity variables; $\beta_{4,1}, \beta_{4,2}$ and $\beta_{4,3}$ are the coefficients for the industry growth rates variables while $\beta_{5, j}$ to $\beta_{13, j}(j=1,2,3)$ are the coefficients of the industry sectors; and finally $\varepsilon_{\mathrm{i}, 1}, \varepsilon_{\mathrm{i}, 2}$ and $\varepsilon_{\mathrm{i}, 3}$ are the error terms for the models 1,2 and 3 respectively. 
Another set of fixed effect models are developed to examine fixed effects in the panel data for the relationship between the industry factors and the firm performance measures. The fixed effects models 4,5 and 6 equally examine the relationship between the industry factors industry concentration, industry capital intensity, industry R\&D intensity, industry growth rates and the industry sectors on the specified performance measure: return on asset, return on equity and Tobin's Q. The fixed effect models in this paper are estimated by least squares dummy variable (LSDV) regression (OLS with a set of dummies) and by within effect estimation methods. The LSDV models for return on asset, return on equity and Tobin's $Q$ are as specified below:

$$
\begin{aligned}
& \text { roa }_{i}=\beta_{0,1}+\beta_{1,1} \text { ind }_{\text {conc }_{i, 1}}+\beta_{2,1} \text { ind }_{\text {capint }_{i, 1}}+\beta_{3,1} \text { ind }_{\text {rdint }}, 1+\beta_{4,1} \text { ind }_{\text {growth }_{i, 1}}+\beta_{5,1} \text { agric }_{i, 1}+\beta_{6,1} \text { conglom }_{i, 1}+ \\
& \beta_{7,1} \text { const }_{r e_{i, 1}}+\beta_{8,1} \text { cons }_{\text {goods }_{i, 1}}+\beta_{9,1} \text { healthcare }_{i, 1}+\beta_{10,1} \text { ict }_{i, 1}+\beta_{11,1} \text { ind }_{\text {goods }_{i, 1}}+\beta_{12,1} \text { nat }_{\text {resrc }}{ }_{i, 1}+\beta_{13,1} \text { oil }_{\text {gas }_{i, 1}}+ \\
& u_{1,1} \text { firm }_{1,1}+u_{2,1} \text { firm }_{2,1}+u_{3,1} \text { firm }_{3,1}+\cdots+u_{113,1} \text { firm }_{113,1}+\varepsilon_{i, 1} \\
& \text { roe }_{i}=\beta_{0,2}+\beta_{1,2} \text { ind }_{\text {conc }_{i, 2}}+\beta_{2,2} \text { ind }_{\text {capint }_{i, 2}}+\beta_{3,2} \text { ind }_{\text {rdint }}{ }_{i, 2}+\beta_{4,2} \text { ind }_{\text {growth }_{i, 2}}+\beta_{5,2} \text { agric }_{i, 2}+ \\
& \beta_{6,2} \text { conglom }_{i, 2}+\beta_{7,2} \text { const }_{r e_{i, 2}}+\beta_{8,2} \text { cons }_{\text {goods }_{i, 2}}+\beta_{9,2} \text { healthcare }_{i, 2}+\beta_{10,2} \text { ict }_{i, 2}+\beta_{11,2} \text { ind }_{\text {goods }_{i, 2}}+ \\
& \beta_{12,2} \text { nat_resrc }_{i, 2}+\beta_{13,2} \text { oil_gas }_{i, 2}+u_{1,2} \text { firm }_{1,2}+u_{2,2} \text { firm }_{2,2}+u_{3,2} \text { firm }_{3,2}+\cdots+u_{113,2} \text { firm }_{113,2}+\varepsilon_{i, 2} \\
& \text { tobinq }_{i}=\beta_{0,3}+\beta_{1,3} \text { ind }_{\text {conc }_{i, 3}}+\beta_{2,3} \text { ind }_{\text {capint }_{i, 3}}+\beta_{3,3} \text { ind }_{\text {rdint }}{ }_{i, 3}+\beta_{4,3} \text { ind }_{\text {growth }_{i, 3}}+\beta_{5,3} \text { agric }_{i, 3}+\beta_{6,3} \text { conglom }_{i, 3}+ \\
& \beta_{7,3} \text { const }_{r i_{i, 3}}+\beta_{8,3} \text { cons }_{\text {goods }_{i, 3}}+\beta_{9,3} \text { healthcare }_{i, 3}+\beta_{10,3} \text { ict }_{i, 3}+\beta_{11,3} \text { ind }_{\text {goods }_{i, 3}}+\beta_{12,3} \text { nat_resrc }_{i, 3}+ \\
& \beta_{13,3} \text { oil_gas }_{i, 3}+u_{1,3} \text { firm }_{1,3}+u_{2,3} \text { firm }_{2,3}+u_{3,3} \text { firm }_{3,3}+\cdots+u_{113,3} \text { firm }_{113,3}+\varepsilon_{i, 3}
\end{aligned}
$$

The variables are as defined for pooled OLS models. firm ${ }_{1,1} \ldots$ firm $_{113,1}$, firm $_{1,2} \ldots$ firm fi13,2 $_{1}$ and firm $_{1,3} \ldots$ firm $_{113,3}$ are dummy variables for the 113 firms in the study (the 114th firm is left out to avoid perfect collinearity). $\mathrm{u}_{1,1} \ldots \mathrm{u}_{113,1}, \mathrm{u}_{1,2} \ldots \mathrm{u}_{113,2}$ and $\mathrm{u}_{1,3} \ldots \mathrm{u}_{113,3}$ are the coefficients of the dummy firm variables.

Although the within group effect estimation method for fixed effects modelling does not use dummy variables, it requires the computation of group means of the firm performance measures and the industry variables. The variables are then transformed by computing their deviations from group means. The transformed firm performance variables are then regressed against the transformed industry variables. The Stata statistical package used in this paper however automatically estimates the within group fixed effects using a single line of command. F-test is used to test whether or not fixed effects exist in the relationship between the industry factors and firm performance.

Lastly the random effects will be estimated for the relationship between industry factors and the firm performance measures. The random effect model in this paper is developed and estimated using the feasible generalized least squares (FGLS) estimation method. Theta $(\theta)$ is first estimated from the between effect estimation (group mean regression) and the sum of squared errors of the within effect estimation or the deviations of residuals from group means of residuals. The group means of industry and firm performance variables are first adjusted by $\theta$ before the variables are transformed by estimating their deviations from the adjusted group means. The transformed firm performance measures are then regressed against the transformed industry variables. Just like for within group effect estimation method in fixed effect modelling, Stata package provides a single command line to estimate random effects models for a specified panel data. The commands are used to estimate within group fixed effects and random effects for the relationships analysed in this paper. LM test is used to examine the existence of random effects in the industry factors - firm performance relationship while Hausman test is used to compare fixed and random effects in the relationship.

\subsubsection{Models for the Effects of Firm-Specific Factors on Firm Performance}

The firm-specific variables identified in this study include relative market share, firm size, diversification, financial leverage, firm age, firm capital intensity, firm R\&D intensity and firm growth rates. The relationship between these firm-specific factors and the firm performance measures are also analysed using pooled OLS, fixed effects and random effects regression methods. The pooled OLS regression models are specified in 7, 8 and 9 for return on asset, return on equity and Tobin's $Q$ performance measures respectively.

$$
\begin{aligned}
& \text { roa }_{i}=\beta_{0,1}+\beta_{1,1} \text { rel_mktshr }_{i, 1}+\beta_{2,1} \text { size }_{i, 1}+\beta_{3,1} \text { divers }_{i, 1}+\beta_{4,1} \text { fin_lev }_{i, 1}+\beta_{5,1} \text { age }_{i, 1}+\beta_{6,1} \text { frm_capint }_{i, 1}+ \\
& \beta_{7,1} \text { frm_rdint }_{i, 1}+\beta_{8,1} \text { frm_growth }_{i, 1}+\varepsilon_{i, 1} \\
& \text { roe }_{i}=\beta_{0,2}+\beta_{1,2} \text { rel_mktshr }_{i, 2}+\beta_{2,2} \text { size }_{i, 2}+\beta_{3,2} \text { divers }_{i, 2}+\beta_{4,2} \text { fin_lev }_{i, 2}+\beta_{5,2} \text { age } e_{i, 2}+\beta_{6,2} \text { frm_capint }_{i, 2}+ \\
& \beta_{7,2} \text { frm_rdint }_{i, 2}+\beta_{8,2} \text { frm }_{-} \text {growth }_{i, 2}++\varepsilon_{i, 2} \\
& \text { tobinq }_{i}=\beta_{0,3}+\beta_{1,3} \text { rel_mktshr }_{i, 3}+\beta_{2,3} \text { size }_{i, 3}+\beta_{3,3} \text { divers }_{i, 3}+\beta_{4,3} \text { fin_lev }_{i, 3}+\beta_{5,3} \text { age }_{i, 3}+\beta_{6,3} \text { frm_capint }_{i, 3}+
\end{aligned}
$$




$$
\beta_{7,3} \text { frm_rdint }_{i, 3}+\beta_{8,3} \text { frm_growth }_{i, 3}++\varepsilon_{i, 3}
$$

The firm performance variables, the intercepts and the error terms are as defined earlier in this paper. rel_mktshr ${ }_{1,1}$, rel_mktshr $_{1,2}$ and rel_mktshr $_{1,3}$ are the relative market share variables for return on asset, return on equity and Tobin's Q firm performance measures respectively; size $e_{1,1}, \operatorname{size}_{1,2}$ and $\operatorname{size}_{1,3}$ are the firm size variables; divers ${ }_{1,1}$, divers ${ }_{1,2}$ and divers ${ }_{1,3}$ are the diversification variables; fin_lev ${ }_{1,1}$, fin_lev ${ }_{1,2}$ and fin_lev lev $_{1,3}$ are the financial leverage variables, age $e_{1,1}$, age $_{1,2}$ and $\mathrm{age}_{1,3}$ are the firm age variables; frm_capint ${ }_{1,1}$, frm_capint $_{1,2}$ and frm_capint ${ }_{1,3}$ are the firm capital intensity variables; frm_rdint ${ }_{1,1}$, frm_rdint fr,2 $_{1,2}$ and frm_rdint $_{1,3}$ are the firm R\&D intensity variables while frm_growth ${ }_{1,1}$, frm_growth fr, $_{1,2}$ and frm_growth fr,3 $_{1,3}$ are the growth rates variables for the three performance measures. $\beta_{1, j}(j=1,2,3), \beta_{2, j}, \beta_{3, j}, \beta_{4, j}, \beta_{5, j}, \beta_{6, j}, \beta_{7, j}$ and $\beta_{8, j}$ and the coefficients of relative market share, firm size, diversification, financial leverage, age, firm capital intensity, firm R\&D intensity and firm growth rates variables respectively.

In order to investigate the relationship for fixed effects, the LSDV models are also specified for the three performance measures.

$$
\begin{aligned}
& \operatorname{roa}_{i}=\beta_{0,1}+\beta_{1,1} \text { rel }_{\text {mktshr }}+1+\beta_{2,1} \text { size }_{i, 1}+\beta_{3,1} \operatorname{divers}_{i, 1}+\beta_{4,1} \text { fin }_{\text {lev }_{i, 1}}+\beta_{5,1} \text { age }_{i, 1}+\beta_{6,1} \text { frm }_{\text {capint }_{i, 1}}+ \\
& \beta_{7,1} \text { frm_rdint }_{i, 1}+\beta_{8,1} \text { frm_growth }_{i, 1}+u_{1,1} \text { firm }_{1,1}+u_{2,1} \text { firm }_{2,1}+u_{3,1} \text { firm }_{3,1}+\cdots+u_{113,1} \text { firm }_{113,1}+\varepsilon_{i, 1} \\
& \text { roe }_{i}=\beta_{0,2}+\beta_{1,2} \text { rel }_{\text {mktshr }}{ }_{i, 2}+\beta_{2,2} \text { size }_{i, 2}+\beta_{3,2} \text { divers }_{i, 2}+\beta_{4,2} \text { fin }_{\text {lev }_{i, 2}}+\beta_{5,2} \text { age }_{i, 2}+\beta_{6,2} \text { frm }_{\text {capint }_{i, 2}}+ \\
& \beta_{7,2} \text { frm_rdint }_{i, 2}+\beta_{8,2} \text { frm_growth }_{i, 2}+u_{2,2} \text { firm }_{2,2}+u_{3,2} \text { firm }_{3,2}+\cdots+u_{113,2} \text { firm }_{113,2}+\varepsilon_{i, 2}
\end{aligned}
$$

tobinq $_{i}=\beta_{0,3}+\beta_{1,3}$ rel_mktshr $_{i, 3}+\beta_{2,3}$ size $_{i, 3}+\beta_{3,3}$ divers $_{i, 3}+\beta_{4,3}$ fin_lev $_{i, 3}+\beta_{5,3}$ age $_{i, 3}+\beta_{6,3}$ frm_capint $_{i, 3}+$ $\beta_{7,3}$ frm_rdint $_{i, 3}+\beta_{8,3}$ frm_growth $_{i, 3}+u_{1,3}$ firm $_{1,3}+u_{2,3}$ firm $_{2,3}+u_{3,3}$ firm $_{3,3}+\cdots+u_{113,3}$ firm $_{113,3}+\varepsilon_{i, 3}$

The terms are as defined earlier in this paper.

The within group fixed effects and the random effects models are also estimated for the relationship between the firm-level factors and firm performance. The F-test, LM test and Hausman tests are carried out to investigate the existence of fixed and random effects in the relationship and to compare the two effects.

\section{Results and Discussion}

This section discusses the results of the models specified in the previous chapter. The models are implemented using Stata statistical package.

\subsection{The Industry and Firm-Level Factors and Firm Performance}

The relative effects of industry- and firm-level factors on firm performance are discussed using the outputs from the pooled OLS, fixed effects and random effects models.

\subsubsection{Effects of Industry Factors on Firm Performance}

The effects of the identified industry factors on the three firm performance measures, return on asset; return on equity and Tobin's Q, are analysed.

1) Effects of Industry Factors on Return on Asset

The results of the pooled OLS model (model 1), fixed effect model (model 4 and the within estimation model) and random effect model are summarised in Table 2. The table shows the effects of the industry factors (industry concentration, industry capital intensity, industry R\&D intensity, industry growth rates and industry sectors) on return on asset (a firm performance measure)

Table 2. Effects of industry factors on return on asset

\begin{tabular}{lrrr}
\hline Return on Asset & Pooled OLS & Fixed Effect Model & Random Effect Model \\
\hline Industry Concentration & $-.0627456(.1733637)$ & $-.2097948(.148954)$ & $-.1810326(.1427089)$ \\
Industry Capital Intensity & $.0002854(.0028995)$ & $.0004613(.0019087)$ & $.0004269(.0019071)$ \\
Industry R\&D Intensity & $-.4635195(1.059421)$ & $-.2996601(.7042882)$ & $-.3317104(.7023563)$ \\
Industry Growth & $-.0024563(.0342942)$ & $.0009075(.0226407)$ & $.0002496(.0226088)$ \\
Agriculture & $.0774571(.0996688)$ & $.0629958(.0977629)$ & $.1396169(.0950248)$ \\
Conglomerates & $.0673881(.102858)$ & $.1239642(.0940355)$ & $.1150913(.0900072)$ \\
Construction / Real Estate & $.0441256(.0955849)$ & $.1108084(.0969122)$ & $.1073743(.0901624)$ \\
Consumer Goods & $.0287852(.0357877)$ & $.0879874(.061751)$ & $.0499603(.0423078)$ \\
Healthcare & $.0217723(.0714348)$ & $.0504155(.0832925)$ & $.0683659(.0703567)$ \\
\hline
\end{tabular}




\begin{tabular}{lrrr}
\hline ICT & $.0637261(.0931194)$ & $.1187874(.0894632)$ & $.1105947(.0835125)$ \\
Industrial Goods & $.0628461(.076844)$ & $.1199962(.0850013)$ & $.1139882(.0707813)$ \\
Natural Resources & $.0394424(.1006025)$ & $.1447397(.0986213)$ & $.1035924(.0989623)$ \\
Oil \& Gas & $.0173430(.0556651)$ & $.0587542(.0710109)$ & $.0521707(.0582694)$ \\
Intercept & $.0440218(.0805364)$ & $.1211951(.0784041)$ & $.0972376(.0692532)$ \\
F-test (Model) & 0.58 & 0.59 & 4.08 \\
DF & 556 & 452 & 452 \\
$\mathrm{R}^{2}$ & 0.0135 & 0.6537 & .1049479 \\
SSE (SRMSE) & 10.00037 & 3.51004 & .0881225 \\
SEE or $\widehat{\boldsymbol{\sigma}}_{\mathrm{v}}$ & .13411 & .08812 & .6484534 \\
$\widehat{\boldsymbol{\sigma}}_{\mathrm{u}}$ & & & $357.89^{* * * *}$ \\
$\Theta$ & & & 570 \\
$\mathrm{Effect}$ Test & & $5.505^{* * *}$ & 570 \\
$\mathrm{~N}$ & 570 & & 570 \\
\hline
\end{tabular}

Standard errors in parenthesis; Statistical significance: ${ }^{*}<.1,{ }^{* *}<0.05,{ }^{* * *} \mathrm{c}<0.01$.

Although the results show that there are fixed and random effects (the effect tests are significant at 0.01 level), the F-test for the whole models (pooled OLS, fixed effect and random effect) are not statistically significant. This means the models cannot be used to explain the relationship between the industry factors and return on asset as a firm performance measure. The data provides little or no evidence that industry factors have any effects on return on asset.

Analysing the coefficients of the industry variables also show that none of the coefficient is statistically significant, there is therefore little or no evidence that any of the industry factors (industry concentration, industry capital intensity, industry R\&D intensity, industry growth and industry sectors) has any relationship with return on asset. According to the data, there is little or no evidence that the variance in return on asset is due to any of the industry-level variables. Return on asset is a key firm performance measure as it measures the ratio of firm's net income to total asset employed by the firm. It thus shows how effective and efficient firms employed their assets to create values for the firms. The findings therefore show that industry factors have little or no effect on how effective and efficient firms employ the assets to make profits and hence on firm performance. The results suggest that factors other than industry factors account for the variance in return on asset.

\section{2) Effects of Industry Factors on Return on Equity}

The results of the pooled OLS model 2, the LSDV fixed effect model 5 and the random effect model for the relationship between the industry factors and return on equity are presented in Table 3 .

Table 3. Effects of industry factors on return on equity

\begin{tabular}{lrrr}
\hline Return on Equity & Pooled OLS & Fixed Effect Model & Random Effect Model \\
\hline Industry Concentration & $-1.856238(2.422848)$ & $-3.750107(3.433804)$ & $-1.856238(2.422848)$ \\
Industry Capital Intensity & $.007332(.0405224)$ & $.0095982(.0440002)$ & $.007332(.0405224)$ \\
Industry R\&D Intensity & $-3.593012(14.80596)$ & $-1.48264(16.2358)$ & $-3.593012(14.80596)$ \\
Industry Growth & $-.0437575(.4792799)$ & $-.000434(.52193)$ & $-.0437575(.4792799)$ \\
Agriculture & $1.053378(1.392923)$ & $1.775956(2.253708)$ & $1.053378(1.392923)$ \\
Conglomerates & $1.142688(1.437494)$ & $1.80948(2.167779)$ & $1.142688(1.437494)$ \\
Construction / Real Estate & $1.258461(1.335849)$ & $2.125881(2.234095)$ & $1.258461(1.335849)$ \\
Consumer Goods & $.560417(.5001522)$ & $.8648848(1.423533)$ & $.560417(.5001522)$ \\
Healthcare & $.8815812(.9983389)$ & $1.392644(1.920125)$ & $.8815812(.9983389)$ \\
ICT & $1.096936(1.301392)$ & $1.713711(2.062377)$ & $1.096936(1.301392)$ \\
Industrial Goods & $.8182235(1.073935)$ & $1.585292(1.959516)$ & $.8182235(1.073935)$ \\
Natural Resources & $1.01531(1.405973)$ & $1.971832(2.273496)$ & $1.01531(1.405973)$ \\
Oil \& Gas & $.7066472(.7779485)$ & $1.053272(1.636999)$ & $.7066472(.7779485)$ \\
Intercept & $.8296306(1.125539)$ & $1.818199(1.807434)$ & $.8296306(1.125539)$ \\
F-test (Model) & 0.17 & & 0.20 \\
DF & 556 & 452 & 2.16 \\
\end{tabular}




\begin{tabular}{lrrr}
\hline $\mathrm{R}^{2}$ & 0.0039 & 0.0487 & \\
SSE (SRMSE) & 1953.2249 & 1865.34357 & \\
SEE or $\widehat{\boldsymbol{\sigma}}_{\mathrm{v}}$ & 1.8743 & 2.0315 & 2.031469 \\
$\widehat{\boldsymbol{\sigma}}_{\mathrm{u}}$ & & & 0 \\
$\theta$ & & & 0 \\
Effect Test & & 0.204 & 0.00 \\
$\mathrm{~N}$ & 570 & 570 & 570 \\
\hline
\end{tabular}

Standard errors in parenthesis; Statistical significance: ${ }^{*}<.1,{ }^{* *}<0.05,{ }^{* * *}<0.01$.

The results show the effects of industry concentration, industry capital intensity, industry R\&D intensity, industry growth rate and the firm's industry sector on return on equity as a measure of firm performance. Just like the results for return on asset, there is little or no evidence to show that industry factors determine firm performance as measured by return on equity. The pooled OLS model for the relationship between the industry factors and return on equity is not statistically significant. The F- and LM tests show that the fixed and random effects are not statistically significant. In addition, the results show that both the fixed and random effect models are not statistically significant. The outputs all show that there is little or no evidence that industry factors studied cause changes in return on equity.

The results for both return on asset and return on equity suggest that industry factors do not cause changes in firm performance. The next section examines the effects of industry factors on firm's market performance measure, Tobin's Q.

3) Effects of Industry Factors on Tobin's Q

The pooled OLS model 3, the LSDV fixed model 6 and the corresponding random effect model are analysed for the relationship between the industry factors and Tobin's Q. The results are shown in Table 4.

Table 4. Effects of industry factors on Tobin's Q

\begin{tabular}{|c|c|c|c|}
\hline Tobin Q & Pooled OLS & Fixed Effect Model & Random Effect Model \\
\hline Industry Concentration & $1.170282(3.179667)$ & $1.372786(1.705603)$ & $1.360496(1.682467)$ \\
\hline Industry Capital Intensity & $-.0127381(.0531803)$ & $-.0129804(.0218553)$ & $-.0129657(.0218333)$ \\
\hline Industry R\&D Intensity & $6.523447(19.43086)$ & $6.297793(8.064475)$ & 6.311488 (8.051595) \\
\hline Industry Growth & $-.3414288(.6289914)$ & $-.3460613(.2592475)$ & $-.3457801(.2589408)$ \\
\hline Agriculture & $-.3795923(1.828027)$ & $-.5339504(1.119438)$ & $-.4795498(1.485142)$ \\
\hline Conglomerates & $-1.11762(1.886521)$ & $-1.119677(1.076756)$ & $-1.19433(1.390241)$ \\
\hline Construction / Real Estate & $-.7687321(1.753125)$ & $-.9285114(1.109696)$ & $-.8704406(1.364418)$ \\
\hline Consumer Goods & $1.934086^{* * *}(.6563836)$ & $.3139145(.707082)$ & $1.900035^{* *}(.7757887)$ \\
\hline Healthcare & $-.3921131(1.310188)$ & $-.7053274(.9537441)$ & -.467039 (1.119442) \\
\hline ICT & $-.1642449(1.707905)$ & $4.417821^{* * *}(1.024402)$ & $-.2396131(1.299757)$ \\
\hline Industrial Goods & $.4280713(1.409397)$ & $-.2085775(.97331)$ & $.345831(1.038015)$ \\
\hline Natural Resources & $-.1821676(1.845153)$ & $.9008722(1.129267)$ & $-.2853255(1.583607)$ \\
\hline Oil \& Gas & $-.2732276(1.020954)$ & $-.5919597(.8131128)$ & $-.3292332(.9858716)$ \\
\hline Intercept & $.0647824(1.477121)$ & $-.3349604(.8977692)$ & -.0207926 (.9177677) \\
\hline F-test (Model) & $5.07^{* * * *}$ & $27.72^{* * *}$ & 17.53 \\
\hline DF & 556 & 452 & 452 \\
\hline $\mathrm{R}^{2}$ & 0.1060 & 0.8777 & \\
\hline SSE (SRMSE) & 3364.05649 & 460.217975 & \\
\hline SEE or $\widehat{\boldsymbol{\sigma}}_{\mathrm{v}}$ & 2.4598 & 1.009 & 1.0090497 \\
\hline$\widehat{\boldsymbol{\sigma}}_{\mathrm{u}}$ & & & 2.3312696 \\
\hline$\theta$ & & & .8099589 \\
\hline Effect Test & & $28.500^{* * *}$ & $783.43^{* * *}$ \\
\hline $\mathrm{N}$ & 570 & 570 & 570 \\
\hline
\end{tabular}

Standard errors in parenthesis; Statistical significance: ${ }^{*}<.1,{ }^{* *}<0.05,{ }^{* * *}<0.01$.

The pooled OLS is statistically significant at 0.01 level showing that industry factors affect Tobin's $Q$, a measure of firm's market performance. However F- and LM tests show that there are significant fixed and random effects 
in the relationship and thus fixed and random effect models are better models than the pooled OLS model. Hausman test to compare the two effects returns -0.45 (Prob>chi2 $=0.4322$ ), the null hypothesis that random effect model is better than the fixed effect model is therefore rejected.

The fixed effect model is statistically significant at 0.01 level and shows that industry factors account for 87.77 percent variance in the values of Tobin's Q. Of the industry factors used (industry concentration, industry capital intensity, industry R\&D intensity, industry growth rate and industry sector), the coefficient of ICT industry sector is the only statistically significant coefficient. The coefficient of 4.417821 at significant level of 0.01 suggests that ICT sector has a strong positive relationship with Tobin's Q. A firm being an ICT firm, all other things being equal, is thus likely to increase Tobin's $\mathrm{Q}$ by 4.14 . The results of the model, in general, suggest that industry-level variables are key determinant of a firm's market performance. The financial analysts and investors strongly consider the industry factors when they buy and sell companies' share on the floor of the stock exchange. A Tobin's $Q$ value greater than 1 shows that the market value of the firm is more than the book value and implies that the firm's stock is somewhat overvalued. It can therefore be inferred from the results that the industry-level factors increase firm's Tobin's $Q$ and thus make the firm to be overvalued. It shows that the market sees future growth opportunities in the firm based on the industry-level variables. Particularly according to the model output, an ICT firm is expected to post superior future income when compared to firms from other industry sectors. It thus implies that the market expects ICT firms to have relatively more future growth opportunities compared to firms from other sectors.

From the model results, the industry to which the firm belongs appears to be the most important industry determinant of firm's market performance.

\subsubsection{Effects of Firm-Level Factors on Firm Performance}

The effects ofthe identified firm-level variables have on firm performance measures (return on asset, return on equity and Tobin's Q) are examined in this section.

\section{1) Effects of Firm-Level Factors on Return on Asset}

The models for the relationship between business-specific factors and return on asset are discussed next. The outputs of the pooled OLS model 7, the LSDV/within group fixed effect model 10 and the random effect model of the relationship are summarised in Table 5. The results show the effects of such business-specific factors as relative market share, firm size, diversification, financial leverage, firm age, firm capital intensity, firm R\&D intensity and firm growth rate on return on asset. The results also show the relative statistical significance of fixed and random effects in the relationship.

Table 5. Effects of firm-level factors on return on asset

\begin{tabular}{|c|c|c|c|}
\hline Return on Asset & Pooled OLS & Fixed Effect Model & Random Effect Model \\
\hline Relative Market Share & $-.0007355(.0069171)$ & $.0662202(.0472915)$ & $.0033494(.0117333)$ \\
\hline Size & $.029492^{* * *}(.00317)$ & $.020174(.017505)$ & $.026757^{* * *}(.005203)$ \\
\hline Diversification & $-.0211987^{* * *}(.006338)$ & $-.0047504(.015866)$ & $-.0149865(.0092941)$ \\
\hline Financial Leverage & $-.1398203^{* * *}(.0395481)$ & $-.0524919(.054235)$ & $-.0956104^{* *}(.0442949)$ \\
\hline Age & $.0000265(.000259)$ & $-.0048314(.0029339)$ & $-.0002038(.0004287)$ \\
\hline Firm Capital Intensity & $-.001214(.0008658)$ & $-.0005274(.0008989)$ & $-.0009285(.0008213)$ \\
\hline Firm R\&D Intensity & $-.0802746(.1059725)$ & $-.4805852^{* *}(.2122004)$ & $-.251273^{*}(.1446268)$ \\
\hline Firm Growth Rate & $.0317447^{* * * *}(.0108238)$ & $.014634(.0092289)$ & $.0197365^{* *}(.0088745)$ \\
\hline Intercept & $-.6013333^{* * *}(.0697008)$ & $-.2595137(.3359616)$ & $-.5411294^{* *}(.1147668)$ \\
\hline F-test /Wald (Model) & $14.25^{* * *}$ & $7.38^{* *}$ & $43.13^{* * *}$ \\
\hline DF & 561 & 448 & 448 \\
\hline $\mathrm{R}^{2}$ & 0.1688 & 0.6658 & \\
\hline SSE (SRMSE) & 8.42513591 & 3.3876434 & \\
\hline SEE or $\widehat{\boldsymbol{\sigma}}_{\mathrm{v}}$ & .12255 & .08696 & .08695806 \\
\hline$\widehat{\boldsymbol{\sigma}}_{\mathrm{u}}$ & & & .08768844 \\
\hline$\theta$ & & & .59459128 \\
\hline Effect Test & & $5.895^{* * *}$ & $260.88^{* * *}$ \\
\hline $\mathrm{N}$ & 570 & 570 & 570 \\
\hline
\end{tabular}

Standard errors in parenthesis; Statistical significance: ${ }^{*}<.1,{ }^{* *}<0.05,{ }^{* * *}<0.01$. 
Although the pooled OLS model is significant at 0.01 level, the F- and LM effect tests show that fixed and random effect models provide better goodness-of-fit and are thus better models for the relationship than pooled OLS. The Hausman test to compare the two effects although returns a value of -14.30 (chi $2<0$ implies random effect more significant) warns that data fails to meet the asymptotic assumptions. We may not therefore conclude that random effect model is better.

Analysing the relationship using both the fixed and random effect models show that the fixed effect model is statistically significant at 0.05 level while the random effect model is significant at 0.01 level. The identified firm-level factors explain about 67 percent of the changes in the values of return on asset. This value when compared to the results of the effects of industry factors on return on asset shows that firm-level factors are relatively more relevant than the industry factors in determining firm performance based on return on asset. The relationships between the firm-level factors and return on asset are explained below:

Relative market share: According to the data, there is little or no evidence that relative market share has any effect on return on asset as a measure of firm performance

Firm size: The coefficient of firm size is statistically significant at 0.01 level. The value of the coefficient is approximately 0.027 . It shows that firm size is positively related to return on asset. All other things being equal, a 1 unit increase in firm size (in terms of natural logarithm of firm's total asset) will lead to a 0.027 increase in return on asset. This suggests that a firm can improve its firm performance by increasing its size, all other things being equal. It also supports extant findings that firm size interacts with other factors to affect firm performance (Arend, 2014).

Diversification: From the results of the random effect model used for the relationship, the coefficient of diversification as a firm-level determinant of firm performance is not significant. The results show that there is little or no evidence that diversification has any effect on return on asset as a measure of firm performance. The findings lend support to mixed results found between diversification and firm performance in extant literature (Graham, Lemmon, \& Wolf, 2002; Hashai, 2015).

Financial leverage: Table $\mathrm{V}$ shows that the relationship between firm's financial leverage and return on asset is statistically significant and negative. The coefficient of financial leverage is -0.09561 and it's significant at 0.05 level. This suggests that financial leverage negatively affects firm performance. A highly levered firm is less likely to record superior performance when compared to an unlevered firm. It thus shows that long term debt does not add value to firms according to data used in the study. The coefficient shows that a 1 unit increase in financial leverage will reduce a firm's return on asset by approximately 0.1 . The results are in support of the findings from other studies which show a negative relationship between financial leverage and firm performance (Boadi, 2015; Kodongo, Mokoaleli-Mokoteli, \& Maina, 2015).

Firm age: The relationship between firm age and return on asset is statistically insignificant according to the model's results. Although the coefficient shows a negative relationship between firm age and return on asset, there is little or no evidence to support this finding. This is however contrary to the finding of a study that shows that firm performance improve with age for the firms in the Italian wine industry (Capasso, Gallucci, \& Rossi, 2015).

Firm capital intensity: The results show that firm capital intensity is insignificantly related to return on asset, a measure of firm performance. It thus offers little or no support to the hypothesis that firms that invest more in long term assets are more likely to be profitable than firm with lower capital asset to net sales ratios. It is however possible that there is a lagged effect of firm capital intensity on firm performance. A follow-up research in this area is therefore needed.

Firm R\&D intensity: The results of the random effect model shows that there is a statistically significant and negative relationship between firm R\&D intensity and return on asset. The results suggest that investing in intangible R\&D investments by a firm will negatively affect the firm's profitability. The findings counter the results from a study that examines R\&D, profits and firm value (Warusawitharana, 2015). The study shows that $R \& D$ investments generate innovations that increase a firm's underlying profitability. This implies that there is a lagged effect of firm R\&D intensity on firm profitability.

Firm growth rate: It is hypothesized that a firm with a high growth rate of net sales is likely to be more profitable than a firm with a low growth rate. The results in Table $\mathrm{V}$ support the hypothesis. The coefficient of firm growth rate at 0.0197365 is statistically significant at 0.05 level. A 1 unit in increase firm growth rate will lead to approximately 0.02 increase in return on asset. Firm growth rate is therefore a key determinant of firm performance. 
Results above have shown that business-specific factors are key determinants of firm profitability.

2) Effects of Firm-Level Factors on Return of Equity

Another measure of firm performance is return on equity. Table 6 shows the results of pooled OLS model 8 , the LSDV fixed effect model 11 (including the within group effect) and random effect model. The results show the relationship between the identified firm-level factors and return on equity as a measure of firm performance.

Table 6. Effects of firm-level factors on return on equity

\begin{tabular}{lrrr}
\hline Return on Equity & Pooled OLS & Fixed Effect Model & Random Effect Model \\
\hline Relative Market Share & $.0245784(.1050047)$ & $.2440377(1.10984)$ & $.0245784(.1050047)$ \\
Size & $.069249(.04815)$ & $-.081418(.410801)$ & $.069249(.048155)$ \\
Diversification & $-.0516857(.0962148)$ & $.0336305(.3723511)$ & $-.0516857(.0962148)$ \\
Financial Leverage & $-1.075957^{*}(.6003596)$ & $-.56693(1.272791)$ & $-1.075957^{*}(.6003596)$ \\
Age & $-.0001175(.0039319)$ & $-.0458749(.0688535)$ & $-.0001175(.0039319)$ \\
Firm Capital Intensity & $.0000399(.0131439)$ & $.0019974(.0210946)$ & $.0000399(.0131439)$ \\
Firm R\&D Intensity & $-.0501266(1.608715)$ & $.5518536(4.979933)$ & $-.0501266(1.608715)$ \\
Firm Growth Rate & $.0501386(.1643113)$ & $-.023725(.2165854)$ & $.0501386(.1643113)$ \\
Intercept & $-1.328647(1.058094)$ & $3.322111(7.88437)$ & $-1.328647(1.058094)$ \\
F-test /Wald (Model) & 0.70 & 0.19 & 5.57 \\
DF & 561 & 448 & 448 \\
$\mathrm{R}^{2}$ & 0.0098 & 0.0485 & \\
SSE (SRMSE) & 1941.55332 & 1865.74496 & 2.0407374 \\
SEE or $\widehat{\boldsymbol{\sigma}}_{\mathrm{v}}$ & 1.8603 & & 0 \\
$\widehat{\boldsymbol{\sigma}}_{\mathrm{u}}$ & & & 0 \\
$\theta$ & & & 0.0407 \\
Effect Test & & & 570 \\
$\mathrm{~N}$ & 570 & 570 & 0.161 \\
\hline
\end{tabular}

Standard errors in parenthesis;Statistical significance: ${ }^{*}<.1,{ }^{* *}<0.05,{ }^{* * *}<0.01$.

None of the three models (pooled OLS, fixed and random effect models) used for the relationship between the firm-level factors and return on equity is statistically significant. The results thus show that there is little or no evidence to show that return on equity, as a measure of firm performance, depends on the specified business-specific variables. The F- and LM tests also show that there are no significant fixed and random effects in the relationship.

Although the coefficients of the factors are not statistically significant (except for financial leverage in the random effect model), they show relationships that are similar to their relationship with return on asset. The coefficients of relative market share, firm size, firm capital intensity and firm growth rates all suggest positive relationships between the factors and return on equity. On the other hand, the coefficients of diversification, firm age, firm R\&D intensity show that the factors are negatively related to return on equity. Explanations similar to those offered for the noticed relationships between the firm-specific factors and return on asset can also be used for the relationships between the factors and return on equity. The coefficient of financial level at -1.075957 is however significant at 0.1 level. This implies that there is a strong negative relationship between financial leverage and return on equity. The negative relationship is also stronger than the one between financial leverage and return on asset. The results show that financial leverage has more negative impact on return on equity than on return on asset.

\section{3) Effects of Firm-Level Factors on Tobin's Q}

The outputs of the pooled OLS model 9, the LSDV fixed effect model 12/within group fixed effect model and the random effect model for the effects of firm-specific factors on Tobin's $Q$ are summarised in Table 7. The results show how the indicated firm-level factors are related to Tobin's Q, a measure of firm's market performance. 
Table 7. Effects of firm-level factors on Tobin Q

\begin{tabular}{|c|c|c|c|}
\hline Tobin Q & Pooled OLS & Fixed Effect Model & Random Effect Model \\
\hline Relative Market Share & $.0455636(.1431289)$ & $-.1892441(.5506388)$ & $-.0156345(.2636842)$ \\
\hline Size & $-.218871^{* * *}(.065639)$ & $-.3213832(.2038158)$ & $-.1985042^{*}(.1084808)$ \\
\hline Diversification & -.0161029 (.1311477) & $-.0201195(.1847391)$ & $-.0252809(.154232)$ \\
\hline Financial Leverage & $-1.419976^{*}(.8183335)$ & $-.3910345(.6314856)$ & $-.3917389(.5891778)$ \\
\hline Age & $-.0074837(.0053595)$ & $.0517743(.0341611)$ & $-.0012481(.0099147)$ \\
\hline Firm Capital Intensity & $-.0263024(.0179161)$ & $-.0007971(.0104659)$ & $-.0015013(.0101758)$ \\
\hline Firm R\&D Intensity & -.9655085 (2.192795) & $-2.087846(2.470755)$ & $-1.521847(2.194998)$ \\
\hline Firm Growth Rate & $.013669(.223968)$ & $-.0456071(.1074572)$ & $-.0615121(.105753)$ \\
\hline Intercept & $6.687091^{* * *}(1.442258)$ & $5.584916(3.911769)$ & $5.867579(2.399956)$ \\
\hline F-test /Wald (Model) & $3.02^{* * *}$ & $26.63^{* * *}$ & 5.54 \\
\hline DF & 561 & 448 & 448 \\
\hline $\mathrm{R}^{2}$ & 0.0414 & 0.8780 & \\
\hline SSE (SRMSE) & 3607.33932 & 459.266494 & \\
\hline $\mathrm{SEE}$ or $\widehat{\boldsymbol{\sigma}}_{\mathrm{v}}$ & 2.5358 & 1.0125 & 1.0124961 \\
\hline$\widehat{\boldsymbol{\sigma}}_{\mathrm{u}}$ & & & 2.3949966 \\
\hline$\theta$ & & & .81422931 \\
\hline Effect Test & & $27.176^{* * * *}$ & $795.73^{* * *}$ \\
\hline $\mathrm{N}$ & 570 & 570 & 570 \\
\hline
\end{tabular}

Standard errors in parenthesis;Statistical significance: ${ }^{*}<.1,{ }^{* *}<0.05,{ }^{* * *}<0.01$.

F- and LM tests are statistically significant indicating that both fixed and random effects exist in the relationship and the fixed and random effect models present better models than the pooled OLS model. Hausman test returns -4.66 with chi $2<0$ implying that random effect model is more significant than fixed effect model but warns that the data fails to meet the asymptotic assumptions. The random effect model for the relationship is not significant while the fixed effect model is statistically significant at 0.01 level. The model shows that firm-level factors account for 87.8 percent of the variance in Tobin's Q. This is slightly more than the proportion accounted for by the industry factors. This shows that there is evidence that a firm's market performance depends on both industry and business-specific factors but slightly more on firm-level factors. The relationships of the firm-level factors with Tobin's Q are however not statistically significant and somewhat different from their corresponding relationships with return on asset and return on equity.

The results show a negative relationship between relative market share and Tobin's $Q$ as opposed to the positive relationship earlier results suggest for the firm-level factor and return on asset and return on equity. Firm size is also shown to be negatively related to Tobin's Q, a finding that is different from the earlier positive firm size return on asset and firm size - return on equity relationships. While the results for the relative market share Tobin's $Q$ relationship may have been limited due to the data used (the computation of relative market shares are restricted to only the listed firms), the negative relationship of firm size with Tobin's Q suggests that the financial analysts/investors do not consider firm size to positively affect firm's market performance However diversification and financial leverage retain the negative relationships they have with return on asset and return on equity. The two factors are also negatively related to Tobin's Q. While results of diversification's effect on firm performance from extant studies have been mixed, financial leverage is shown here to negatively affect firm performance. The results in this paper go further to suggest that financial leverage is negatively related to firm's market performance.

The results for age - Tobin's Q relationship is not conclusive as the models give conflicting results. For the relationship between firm capital intensity and Tobin's Q, the results suggest that firm capital intensity is negatively related to firm's market performance. This may imply that the performance of a firm's stock on the floor of a stock exchange does not depend on the intensity of capital investments made by the firm. However as discussed for return on asset and return on equity, the effect of firm capital intensity on Tobin's Q may be a lagged effect whereby the effect of capital investments by a firm does not reflect on the firm's profitability in the year the investments are made but in subsequent years. The same explanation may be used for the negative relationship observed between firm R\&D intensity and Tobin's Q. Finally Table VII shows that the relationship between firm growth rate and Tobin's $Q$ is insignificant and negative. This is contrary to the positive effects the factor has on return on asset and on return on equity as measures of firm performance. The results may therefore 
suggest that to the stock market investors, a firm's favourable growth in net sales may not translate to improved profitability.

Table 8summarises the evidence for the relative importance of industry and firm-level factors on the three firm performance measures: return on asset, return on equity and Tobin's $Q$ ratio.

Table 8. Relative effect of industry- and firm-level factors on firm performance

\begin{tabular}{llll}
\hline $\begin{array}{l}\text { Firm Performance } \\
\text { Measures / Determinants }\end{array}$ & Return on Asset & $\begin{array}{l}\text { Return on } \\
\text { Equity }\end{array}$ & Tobin's Q ratio \\
\hline Industry-level factors & Little or no evidence & $\begin{array}{l}\text { Little or no } \\
\text { evidence }\end{array}$ & $\begin{array}{l}\text { Significant evidence; accounts for } 87.77 \% \\
\text { variance. Industry sector most relevant }\end{array}$ \\
Firm-level factors & $\begin{array}{l}\text { Significant evidence; accounts for 66.58\% } \\
\text { variance. Financial leverage, firm size and } \\
\end{array}$ & $\begin{array}{l}\text { Little or no } \\
\text { evidence }\end{array}$ & $\begin{array}{l}\text { Significant evidence; accounts for } 87.80 \% \\
\text { variance }\end{array}$ \\
& firm growth rate most relevant & \\
\hline
\end{tabular}

The results show that business-specific factors are relatively more important than industry-level factors as determinants of firm performance. The results support findings from extant literature that business-specific factors account for the larger variance in firm performance when compared to industry-level factors (Chaddad \& Mondelli, 2013; Goddard, Tavakoli, \& Wilson, 2005; McGahan \& Porter, 1997; Roquebert, Phillips, \& Westfall, 1996; Rumelt, 1991).

\section{Conclusions}

The research examines the relative importance of industry- and firm-level factors on firm performance using the data from firms listed on the Nigerian Stock Exchange. It extends the study on drivers of firm performance by examining the effects of the industry- and firm-level factors on firm performance using data from a key developing economy in Africa. The results show that there is little or no evidence that the industry-level factors considered in this paper (industry concentration, industry capital intensity, industry R\&D intensity, industry growth rate and the industry sector) have any effect on two of the three performance ratios used (ROA and ROE). This shows that in a developing country like Nigeria, the industry to which a firm belongs plays little or no role in the expected performance of the firm. The results however provide evidence that industry factors have significant effect on firm market performance (Tobin's Q). The industry to which a firm belongs appears to be the most relevant industry-level determinant of firm's market performance. Follow-on research in a similar economy is however needed to further explore the relationship..

On the other hand, the firm-level factors considered in this paper have significant effect on return on asset, a key firm performance measure, accounting for 66.68 percent of the variation in ROA. The factors also account for 87.8 percent of variation in Tobin's Q, a firm market performance, a figure slightly higher than that of industry-level factors. The results thus show that firm-level factors are relatively more important than the industry-level factors in the determination of firm performance. In terms of the individual relevance of the firm-level factors; financial leverage, firm size and firm growth rate appear to be the most relevant firm-level determinants of firm performance. In as much as the industry to which a firm belongs is important, firms need to consider more their firm-level strategies in order to become relatively more competitive and sustain their competitive advantages.

\section{References}

Ahamed, W. S., Almsafir, M. K., \& Al-Smadi, A. W. (2014). Does Corporate Social Responsibility Lead to Improve in Firm Financial Performance? Evidence from Malaysia. International Journal of Economics and Finance, 6(3), 126-38. http://ccsenet.org/journal/index.php/ijef/issue/archive

Aktas, N., Croci, E., \& Petmezas, D. (2015). Is Working Capital Management Value-Enhancing? Evidence from Firm Performance and Investments. Journal of Corporate Finance, 30, 98-113. http://dx.doi.org/10.1016/j.jcorpfin.2014.12.008

Anwar, S., \& Sun, S. (2015). Unionisation and Firm Performance in China's Manufacturing Industries. Journal of Labor Research, 36(1), 78-102. http://dx.doi.org/10.1007/s12122-014-9197-1

Arend, R. J. (2014). Entrepreneurship and Dynamic Capabilities: How Firm Age and Size Affect the 'Capability Enhancement-SME Performance' Relationship. Small Business Economics, 42(1), 33-57. http://dx.doi.org/10.1007/s11187-012-9461-9 
Arvanitis, S., \& Loukis, E. N. (2013). Outsourcing and Firm Performance--A Comparative Study of Swiss and Greek Firms. Industrial and Corporate Change, 22(3), 771-806.

Baik, B., Chae, J., Choi, S., \& Farber, D. B. (2013). Changes in Operational Efficiency and Firm Performance: A Frontier Analysis Approach. Contemporary Accounting Research, 30(3), 996-1026. http://onlinelibrary.wiley.com/journal/10.1111/\%28ISSN\%291911-3846/issues

Bain, J. S. (1954). Economies of Scale, Concentration, and the Condition of Entry in Twenty Manufacturing Industries. American Economic Review, 44(1), 15-39.

Barney, J. (1991). Firm Resources and Sustained Competitive Advantage. Journal of Management, 17(1), 99-121.

Barney, J. (2011). Firm Resources and Sustained Competitive Advantage. Competitive Strategy, 2, 33-54.

Barrick, M. R., Thurgood, G. R., Smith, T. A., \& Courtright, S. H. (2015). Collective Organizational Engagement: Linking Motivational Antecedents, Strategic Implementation, and Firm Performance. Academy of Management. http://dx.doi.org/10.5465/amj.2013.0227

Boadi, E. K. (2015). An Empirical Analysis of Leverage and Financial Performance of Listed Non-Financial Firms in Ghana. International Journal of Economics and Finance, 7(9), 120-135. http://dx.doi.org/10.5539/ijef.v7n9p120

Bowman, E. H., \& Helfat, C. E. (2001). Does Corporate Strategy Matter? Strategic Management Journal, 22(1), $1-23$.

Brammer, S., \& Millington, A. (2008). Does it pay to be different? An analysis of the relationship between corporate social and financial performance. Strategic Management Journal, 29(12), 1325-1343.

Capasso, A., Gallucci, C., \& Rossi, M. (2015). Standing the Test of Time: Does Firm Performance Improve with Age? An Analysis of the Wine Industry. Business History, 57(7-8), 1037-53. Retrieved from http://www.tandfonline.com/loi/fbsh20

Chaddad, F. R., \& Mondelli, M. P. (2013). Sources of Firm Performance Differences in the US Food Economy. Journal of Agricultural Economics, 64(2), 382-404. http://dx.doi.org/10.1111/j.1477-9552.2012.00369.x

Chadwick, C., Super, J. F., \& Kwon, K. (2015). Resource orchestration in practice: CEO emphasis on SHRM, commitment-based HR systems, and firm performance. Strategic Management Journal, 36(3), 360-376. http://dx.doi.org/10.1002/smj.2217

Chae, H. C., Koh, C. E., \& Prybutok, V. R. (2014). Information Technology Capability and Firm Performance: Contradictory Findings and their Possible Causes. MIS Quarterly, 38(1), 305-341.

Chung, C. N., \& Luo, X. R. (2013). Leadership succession and firm performance in an emerging economy: Successor origin, relational embeddedness, and legitimacy. Strategic Management Journal, 34(3), 338-357. http://dx.doi.org/10.1002/smj.2011

Church, J., \& Ware, R. (2000). Industrial Organization: A Strategic Approach. Boston: Irwin McGraw-Hill.

Dencker, J. C., \& Gruber, M. (2015). The effects of opportunities and founder experience on new firm performance. Strategic Management Journal, 36(7), 1035-1052. http://dx.doi.org/10.1002/smj.2269

Eisenbeiss, S., Knippenberg, D., \& Fahrbach, C. (2015). Doing Well by Doing Good? Analyzing the Relationship Between CEO Ethical Leadership and Firm Performance. Journal of Business Ethics, 128(3), 635-651. http://dx.doi.org/10.1007/s10551-014-2124-9

Ekholm, A., \& Maury, B. (2014). Portfolio Concentration and Firm Performance. Journal of Financial \& Quantitative Analysis, 49(4), 903-931. Retrieved from http://journals.cambridge.org/action/displayBackIssues?jid=JFQ

Fosu, S. (2013). Capital structure, product market competition and firm performance: Evidence from South Africa. Quarterly Review of Economics \& Finance, 53(2), 140-151. http://dx.doi.org/10.1016/j.qref.2013.02.004

Giovannetti, G., Ricchiuti, G., \& Velucchi, M. (2013). Location, Internationalization and Performance of Firms in Italy: A Multilevel Approach. Applied Economics, 45(16-18), 2665-73. http://dx.doi.org/10.1080/00036846.2012.665597

Goddard, J., Tavakoli, M., \& Wilson, J. O. (2005). Determinants of Profitability in European Manufacturing and Services: Evidence from a Dynamic Panel Model. Applied Financial Economics, 15(18), 1269-82. 
http://dx.doi.org/10.1080/09603100500387139

Graham, J. R., Lemmon, M. L., \& Wolf, J. G. (2002). Does Corporate Diversification Destroy Value? Journal of Finance, 57(2), 695-720.

Gschwandtner, A. (2012). Evolution of Profit Persistence in the USA: Evidence from Three Periods. The Manchester School, 80(2), 172-209. http://dx.doi.org/10.1111/j.1467-9957.2011.02277.x

Hashai, N. (2015). Within-industry diversification and firm performance-an S-shaped hypothesis. Strategic Management Journal, 36(9), 1378-1400. http://dx.doi.org/10.1002/smj.2290

Huang, W., \& Boateng, A. (2013). The Role of the State, Ownership Structure, and the Performance of Real Estate Firms in China. Applied Financial Economics, 23(10-12), 847-59. Retrieved from http://www.tandfonline.com/loi/rafe20

Jayachandran, S., Kalaignanam, K., \& Eilert, M. (2013). Product and environmental social performance: Varying effect on firm performance. Strategic Management Journal, 34(10), 1255-1264. http://dx.doi.org/10.1002/smj.2054

Kaczmarek, S., Kimino, S., \& Pye, A. (2014). Interlocking Directorships and Firm Performance in Highly Regulated Sectors: The Moderating Impact of Board Diversity. Journal of Management and Governance, 18(2), 347-72. http://dx.doi.org/10.1007/s10997-012-9228-3

Kahle, K. M., \& Shastri, K. (2005). Firm Performance, Capital Structure, and the Tax Benefits of Employee Stock Options. Journal of Financial \& Quantitative Analysis, 40(1), 135-160. Retrieved from http://journals.cambridge.org/action/displayBackIssues?jid=JFQ

Kodongo, O., Mokoaleli-Mokoteli, T., \& Maina, L. N. (2015). Capital structure, profitability and firm value: Panel evidence of listed firms in Kenya. The African Finance Journal, 17(1). Retrieved from http://www.africagrowth.com/afjabstracts.htm

McGahan, A. M., \& Porter, M. E. (1997). How Much Does Industry Matter, Really? Strategic Management Journal, 18, 15-30.

Mironov, M. (2013). Taxes, Theft, and Firm Performance. Journal of Finance, 68(4), 1441-72. Retrieved from http://onlinelibrary.wiley.com/journal/10.1111/\%28ISSN\%291540-6261/issues

Nielsen, B. B., \& Nielsen, S. (2013). Top management team nationality diversity and firm performance: A multilevel study. Strategic Management Journal, 34(3), 373-382. http://dx.doi.org/10.1002/smj.2021

Peni, E. (2014). CEO and Chairperson Characteristics and Firm Performance. Journal of Management and Governance, 18(1), 185-205. http://dx.doi.org/10.1007/s10997-012-9224-7

Piget, P., \& Kossai, M. (2013 ). The Relationship between Information and Communication Technology Use and Firm Performance in Developing Countries: A Case Study of Electrical and Electronic Goods Manufacturing SMEs in Tunisia. African Development Review/Revue Africaine de Developpement,, 25(3), 330-43. Retrieved from http://onlinelibrary.wiley.com/journal/10.1111/\%28ISSN\%291467-8268/issues

Richard, O. C. (2000). Racial Diversity, Business Strategy, and Firm Performance: A Resource-Based View. Academy of Management Journal, 43(2), 164-177. http://dx.doi.org/10.2307/1556374

Roquebert, J. A., Phillips, R. L., \& Westfall, P. A. (1996). Markets Vs. Management: What 'Drives' Profitability? Strategic Management Journal, 17(8), 653-664.

Rumelt, R. P. (1991). How Much Does Industry Matter? Strategic Management Journal, 12(3), 167-185.

Santos, J. B., \& Brito, L. A. (2012). Toward a Subjective Measurement Model for Firm Performance. BAR, Rio de Janeiro, 9 (Special Issue art. 6), 95-117.

Schmalensee, R. (1985). Do Markets Differ Much? American Economic Review, 75(3), 341-51.

Shan, J., \& Jolly, D. R. (2013). Technological Innovation Capabilities, Product Strategy, and Firm Performance: The Electronics Industry in China. Journal of Administrative Sciences, 30(3), 159-72. http://dx.doi.org/10.1002/CJAS.1256

Shehu, A. M., \& Mahmood, R. (2014). Influence of Entrepreneurial Orientation and Business Environment on Small and Medium Firm Performance: A PLS Approach. Advances in Management and Applied Economics, 4(4), 101-14. Retrieved from http://www.scienpress.com/journal_focus.asp?main_id=55\&Sub_id=IV

Short, J. C., Ketchen Jr., D. J., Bennett, N., \& du Toit, M. (2006). An Examination of Firm, Industry, and Time 
Effects on Performance Using Random Coefficients Modeling. Organizational Research Methods, 9(3), 259-284.

Warusawitharana, M. (2015). Research and Development, Profits, and Firm Value: A Structural Estimation. Quantitative Economics, 6(2), 531-65. Retrieved from http:/qeconomics.org/ojs/index.php/qe/issue/archive

Wernerfelt, B. (1984). A resource-based view of the firm. Strategic Management Journal, 5(2), 171-180.

Wernerfelt, B. (2013). Small forces and large firms: Foundations of the RBV. Strategic Management Journal, 34(6), 635-643. http://dx.doi.org/10.1002/smj.2043

Yang, T. (2013). Change in Governance Environment and Firm Performance: Evidence from Foreign Firms Deregistering from the US. Applied Financial Economics, 23(16-18), $1383-91$. http://dx.doi.org/10.1080/09603107.2013.824545

Yang, T., \& Zhao, S. (2014). CEO Duality and Firm Performance: Evidence from an Exogenous Shock to the Competitive Environment. Journal of Banking and Finance, 49, 534-52. http://dx.doi.org/10.1016/j.jbankfin.2014.04.008

Yang, Z., \& Zhang, H. (2013). Optimal Capital Structure with an Equity-for-Guarantee Swap. Economics Letters, 118(2), 355-59. http://dx.doi.org/10.1016/j.econlet.2012.11.023

\section{Copyrights}

Copyright for this article is retained by the author(s), with first publication rights granted to the journal.

This is an open-access article distributed under the terms and conditions of the Creative Commons Attribution license (http://creativecommons.org/licenses/by/4.0/). 